\title{
Are cytological parameters of maize landraces (Zea mays ssp. mays) adapted along an altitudinal cline?
}

\author{
María Florencia Fourastié ${ }^{1,2} \cdot$ Alexandra Marina Gottlieb ${ }^{1,2} \cdot$ Lidia Poggio $^{1,2} \cdot$ Graciela Esther González $^{1,2}$
}

Received: 28 April 2017 / Accepted: 2 October 2017

(c) The Botanical Society of Japan and Springer Japan KK, part of Springer Nature 2017

\begin{abstract}
The Northwestern Argentina (NWA) highland region is one of the southernmost areas of native maize cultivation. We studied variations of different cytological parameters, such as DNA contents, presence/absence of B chromosomes (Bs), and number and sequence composition of heterochromatic knobs in ten accessions of four maize landraces growing along a broad altitudinal cline in NWA. The aim of this work was to assess variations in cytological parameters and their relationship with the crop altitude of cultivation, in an adaptive context. The A-DNA content of the A chromosome complements showed $40 \%$ of difference between the lowest $(4.5 \mathrm{pg})$ and the highest $(6.3 \mathrm{pg}) 2 \mathrm{C}$ value. This variation could be attributed to differences in number and size of heterochromatic knobs. Fluorescent in situ hybridization studies revealed the sequence composition of each knob, with a higher proportion of knobs composed of 180-bp repeats rather than TR-1 repeats, in all accessions. We also found numerical polymorphisms and the highest frequency of Bs reported in maize to this date. These results lead us to propose that the frequencies and doses of Bs are influenced by the landrace genotypical make-up. The Bs might be maintained in higher frequencies in those accessions having lower heterochromatin content, so as to preserve an optimal nucleotype. Furthermore, selective forces acting along the altitudinal gradient might be modulating the cytological parameters studied, as suggested by the significant correlations found among them.
\end{abstract}

Keywords B chromosomes $\cdot$ DNA content $\cdot$ FISH $\cdot$ Knobs $\cdot$ Maize landraces

\section{Introduction}

Maize (Zea mays ssp. mays L., Poaceae) is widely distributed throughout the American continent, being grown in a variety of agro-ecological areas, from the lowlands up to the highland Andes (Kato et al. 2009; McClintock et al. 1981). A great number of landraces $(>300)$ are currently grown by indigenous farmers in southern South America, with little

Electronic supplementary material The online version of this article (https://doi.org/10.1007/s10265-017-0996-3) contains supplementary material, which is available to authorized users.

Graciela Esther González

gegonzalez@ege.fcen.uba.ar

1 Laboratorio de Citogenética y Evolución (LaCyE), Departamento de Ecología, Genética y Evolución, Facultad de Ciencias Exactas y Naturales, Universidad de Buenos Aires, Buenos Aires, Argentina

2 Instituto de Ecología, Genética y Evolución de Buenos Aires (IEGEBA), CONICET-Universidad de Buenos Aires, Buenos Aires, Argentina or no input of commercial inbred lines. The Andean region is one of the most important centers of maize diversity, and Northern Argentina is the southernmost area of native maize cultivation. In spite of its marginal location, the highlands in Northwestern Argentina (NWA) harbor ca. 30 different landraces (Bracco et al. 2009; Cámara Hernández et al. 2012; Lia et al. 2009).

At the cytological level, previous studies showed great variability in the DNA contents (2C values) of different maize inbred lines and landraces from the American continent, ranging from 4.87 to 7.11 pg (Díez et al. 2013; McMurphy and Rayburn 1991; Rayburn 1990; Rayburn et al. 1985, 1989, 1993; Rosato et al. 1998; Tito et al. 1991). The relationships between the DNA contents in maize landraces and their cultivation altitudes were assessed with contradictory results (Díez et al. 2013; Rayburn 1990; Rayburn and Auger 1990; Rosato et al. 1998). For instance, negative correlations were detected in Southwestern USA populations and in landraces from the Andean NWA (Poggio et al. 1998; Rayburn and Auger 1990; Rosato et al. 1998), whereas a positive correlation was evidenced in USA populations 
cultivated from sea level to $1,600 \mathrm{~m}$ above sea level (m.a.s.l.) (Rayburn 1990). In the light of these results, Bullock and Rayburn (1991) postulated that selection pressure might reduce the DNA contents at both the highest and the lowest altitudes. Furthermore, the DNA content has also been associated with physiological features, such as vegetative period (interval from sowing to anthesis of tassel flowers), and cold and freeze tolerance, for which positive correlations were reported (Greilhuber and Leitch 2013; Poggio et al. 1998; Realini et al. 2016; Tito et al. 1991).

The variation in maize DNA content has been attributed to differences in the percentage of heterochromatin and/or to the presence/absence of B chromosomes (Bs) (Greilhuber and Leitch 2013). Heterochromatic knobs are a cause of variation in $2 \mathrm{C}$ values, since they are variable in size and number. Knobs were found to be located at 22 specific positions on each of the ten chromosomes of the haploid complement of maize (Fourastié 2015; González et al. 2013; Kato 1976; Mondin et al. 2014). Knobs are mainly composed of either of two tandemly repeated DNA sequences, i.e., 180-bp repeat unit (Peacock et al. 1981) and TR-1 of 350-bp repeat (Ananiev et al. 1998). The TR-1 could have evolved from the 180-bp sequence by duplication and divergence (Ananiev et al. 1998). Opposite correlations between the mean number of knobs and the plant cultivation latitudes or altitudes were reported in several populations from across America (McMurphy and Rayburn 1992; Rosato et al. 1998; Tito et al. 1991). Moreover, positive relationships were reported among the number of knobs, heterochromatin percentages and DNA contents (Fourastié 2015; Poggio et al. 1998; Realini et al. 2016; Tito et al. 1991).

The presence/absence of accessory chromosomes or Bs was proposed as another source of variation in the DNA contents. These chromosomes are dispensable genetic elements which lack homology with any member of the normal complement (the A chromosome set) and show non-Mendelian inheritance through accumulation mechanisms (Puertas et al. 2000). Bs are of particular interest in maize cytogenetics, and numerical polymorphisms were described (Bretting and Goodman 1989; Chiavarino et al. 1995; McClintock et al. 1981; Porter and Rayburn 1990; Rosato et al. 1998). Maize population studies that tested the relationship between the frequency of Bs and environmental and cytogenetical variables yielded somewhat opposite results. For instance, the frequency of Bs showed a negative correlation with the cultivation altitude in Mesoamerican populations (Bretting and Goodman 1989), whereas no association was found in the samples from Arizona (Porter and Rayburn 1990). However, a positive correlation was found in NWA native populations (Poggio et al. 1998; Rosato et al. 1998). Molecular studies showed that selective forces affected the maintenance of the altitudinal cline of Bs in NWA landraces (Lia et al. 2007); for those landraces a significant negative correlation was found between the mean number of Bs and the DNA contents of the A chromosome set (Poggio et al. 1998; Rosato et al. 1998).

The aim of this work was to assess the variations in cytological parameters and their relationships with the cultivation altitude of NWA maize landraces growing along a broad altitudinal cline, in order to determine the adaptive value of these parameters. The present report contributes to a comprehensive knowledge on these valued genetic resources, which in turn could be employed in future maize breeding and conservation programs, and provides a thorough understanding of the cytological dynamics at the inter- and intraracial levels.

\section{Materials and methods}

\section{Plant materials}

Maize landraces were sampled in the Provinces of Salta and Jujuy, Argentina (Fig. 1; Table 1). Collection sites were chosen to cover an altitudinal range from 910 to 3900 m.a.s.l. Racial identification was performed on the basis of morphological traits. The materials were deposited at the "Banco de Germoplasma del Laboratorio de Recursos Genéticos Vegetales N.I. Vavilov, Universidad de Buenos Aires", and given corresponding accession numbers (VAV).

\section{Cytological preparations}

Mitotic metaphase plates were obtained for the estimation of mean numbers of Bs and knobs, heterochromatin contents, total chromosome lengths, and sequence compositions of the knobs. Root tips were pre-treated with 0.002 M 8-hydroxyquinoline at room temperature for $5 \mathrm{~h}$, and then fixed in absolute ethanol plus acetic acid solution (3:1) until use. A 10 min wash with a buffer solution (citric acid-sodium citrate $0.01 \mathrm{M}, \mathrm{pH} 4.6$ ) was applied before and after an enzymatic treatment with $2 \%$ cellulase (Onozuka R10, Merck ${ }^{\circledR}$ ) and $20 \%$ pectinase $\left(\right.$ SIGMA $^{\circledR}$ ) in aqueous solution for one hour at $40{ }^{\circ} \mathrm{C}$. Root tips were squashed on a slide with a drop of acetic acid $45 \%\left(\mathrm{v} \mathrm{v}^{-1}\right)$. Cover slides were removed by freezing, and the preparations were air-dried until use.

\section{DAPI staining}

Cytological preparations were stained with a drop of DAPI (4'-6-diamino-2-phenylindole) and incubated in darkness for $20 \mathrm{~min}$ at room temperature. Then, the slides were gently washed with $4 \times$ saline-sodium citrate buffer (SSC, $3 \mathrm{M}$ $\mathrm{NaCl}, 0.3 \mathrm{M}$ sodium citrate, $\mathrm{pH}$ 7) mounted with a drop of Vectashield $\left(\right.$ Vector $\left.^{\circledR}\right)$ anti-fade solution and each slide was covered with a glass coverslip. 
Fig. 1 Geographical locations of the populations studied. a South America; the square indicates the NWA region in Argentina. b Detail of the NWA region

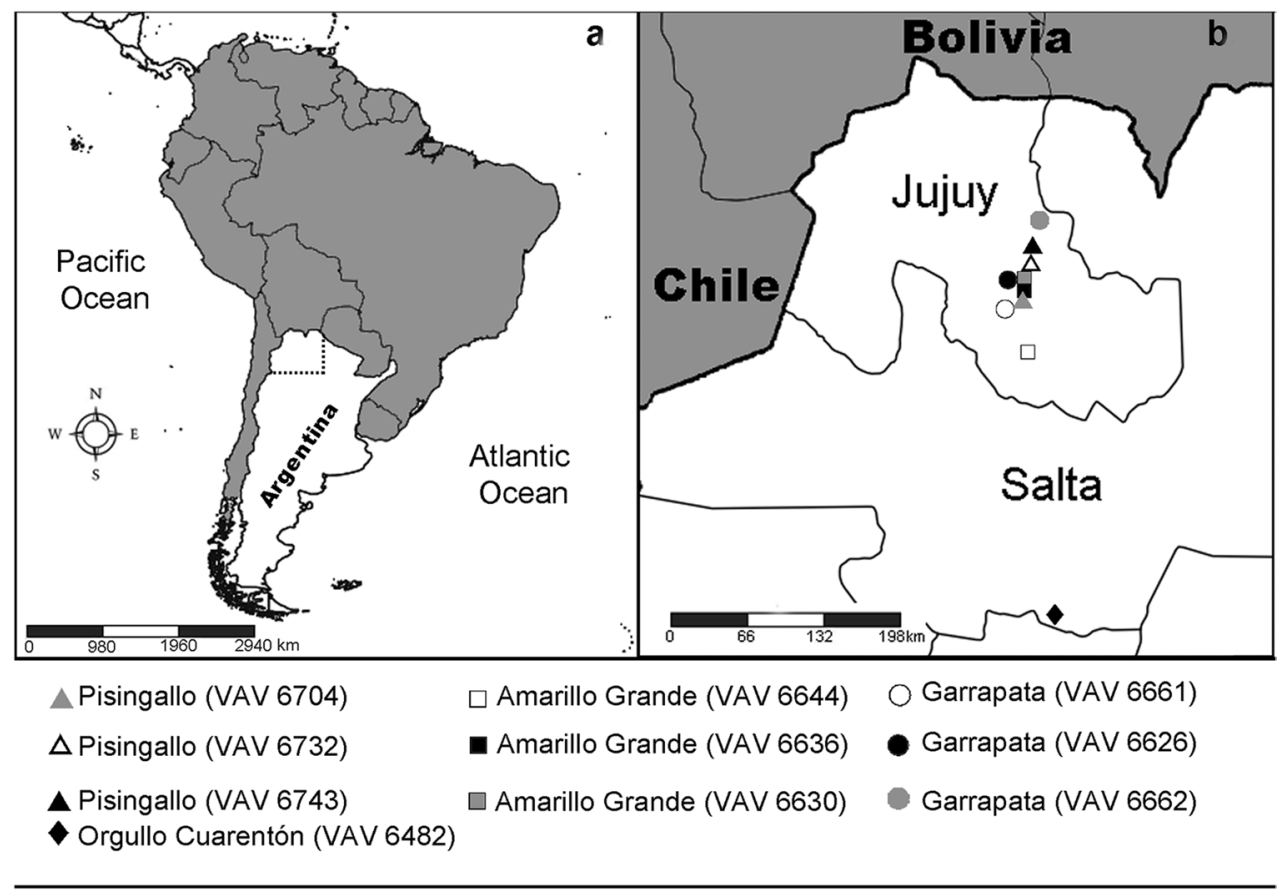

Table 1 Northwestern Argentina maize landraces studied

\begin{tabular}{|c|c|c|}
\hline Landrace & Accession & Collection site \\
\hline Orgullo Cuarentón & VAV 6482 & La Candelaria, Dpt. La Candelaria, Prov. Salta (260.6 $\left.24.7^{\prime \prime} \mathrm{S}-65^{\circ} 09^{\prime} 13.9^{\prime \prime} \mathrm{W}\right)$ \\
\hline Pisingallo & VAV 6704 & La Posta de Hornillos, Dpt. Tilcara, Prov. Jujuy $\left(23^{\circ} 39^{\prime} 19.9^{\prime \prime} \mathrm{S}-65^{\circ} 25^{\prime} 00.0^{\prime \prime} \mathrm{W}\right)$ \\
\hline Pisingallo & VAV 6743 & Calete, Dpt. Humahuaca, Prov. Jujuy $\left(23^{\circ} 14^{\prime} 45.9^{\prime \prime} \mathrm{S}-65^{\circ} 19^{\prime} 05.5^{\prime \prime} \mathrm{W}\right)$ \\
\hline Pisingallo & VAV 6732 & Colonia San José, Huacalera, Dpt. Tilcara, Prov. Jujuy $\left(23^{\circ} 23^{\prime} 30.0^{\prime \prime} \mathrm{S}-65^{\circ} 20^{\prime} 37.0^{\prime \prime} \mathrm{W}\right)$ \\
\hline Amarillo Grande & VAV 6636 & Huichaira, Dpt. Tilcara, Prov. Jujuy $\left(23^{\circ} 35^{\prime} 47.4^{\prime \prime} \mathrm{S}-65^{\circ} 23^{\prime} 05.1^{\prime \prime} \mathrm{W}\right)$ \\
\hline Amarillo Grande & VAV 6644 & Bárcena, Dpt. Humahuaca, Prov. Jujuy $\left(24^{\circ} 04^{\prime} 35.9^{\prime \prime S}-65^{\circ} 21^{\prime} 34.6^{\prime \prime W}\right)$ \\
\hline Amarillo Grande & VAV 6630 & Jueya, Dpt. Tilcara, Prov. Jujuy $\left(23^{\circ} 30^{\prime} 45.6^{\prime \prime S}-65^{\circ} 23^{\prime} 19.7^{\prime \prime} \mathrm{W}\right)$ \\
\hline Garrapata & VAV 6661 & 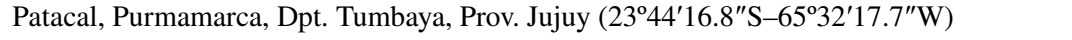 \\
\hline Garrapata & VAV 6626 & Jueya, Dpt. Tilcara, Prov. Jujuy $\left(23^{\circ} 30^{\prime} 55.8^{\prime \prime S}-65^{\circ} 30^{\prime} 38.1^{\prime \prime} \mathrm{W}\right)$ \\
\hline Garrapata & VAV 6662 & Comunidad Ronque, Rodero, Dpt. Humahuaca, Prov. Jujuy $\left(23^{\circ} 03^{\prime} 06.6^{\prime \prime} \mathrm{S}-65^{\circ} 16^{\prime} 21.5^{\prime \prime} \mathrm{W}\right)$ \\
\hline
\end{tabular}

Dpt department, Prov province

\section{Amplification and Labeling of DNA probes}

The 180-bp and TR-1 knob sequences were obtained from the GenBank and used to design primer pairs with the Primer3 software (Rozen and Skaletsky 2000). The forward and reverse primers designed were as follows, 5'-ATAGCCATGAACGACCATTT-3' and 5'-ACC CCACATATGTTTCCTTG-3' for the 180-bp probe; and 5'-TCAACTTTTAAACCACAAATGATG-3' and 5'-GTT TGGACAGTTCACTCACACA-3' for the TR-1 probe, respectively. Total genomic DNA was obtained from the maize landrace Orgullo Cuarentón (VAV 6482) using the Wizard ${ }^{\circledR}$ Genomic DNA Purification Kit. The PCR amplification was performed using $100 \mathrm{ng}$ of genomic DNA, $200 \mu \mathrm{M}$ of dNTPs mix, $2.5 \mu \mathrm{l}$ of $\mathrm{Cl}_{2} \mathrm{Mg}(2.5 \mathrm{mM})$,
$0.1 \mu \mathrm{l}$ of Taq polymerase (Invitrogen), $2.5 \mu \mathrm{l}$ of buffer 10 $\times$ (Invitrogen), $2 \mu \mathrm{l}$ of $0.1 \mathrm{nmol} \mathrm{ml} l^{-1}$ of each primer and double distilled water to a final volume of $25 \mu$. The PCR amplification was carried out at an annealing temperature of $47{ }^{\circ} \mathrm{C}$. Amplification products were checked in $1.5 \%$ $\left(\mathrm{w} \mathrm{v}^{-1}\right)$ agarose gel electrophoresis. Probe labeling was done using a master mix consisting of $100 \mathrm{ng}^{-1} \mathrm{l}^{-1}$ of the amplified DNA, $5.0 \mu \mathrm{l}$ of equal amounts of dATP, dGTP and dCTP; $0.2 \mu$ of digoxigenin or biotin labeled dUTP (digoxigenin-11-dUTP or biotin-16-dUTP, Roche), $2.5 \mu \mathrm{l}$ of $\mathrm{Cl}_{2} \mathrm{Mg}, 0.15 \mu \mathrm{l}$ of Taq polymerase, $2.5 \mu \mathrm{l}$ of buffer $10 \times$, $0.1 \mathrm{nmol} \mathrm{ml}^{-1}$ of primers, and completed up to $25 \mu \mathrm{l}$ with double distilled water. Labeled probes were subsequently used for in situ hybridization. 


\section{Fluorescent in situ hybridization (FISH)}

FISH was carried out following González et al. (2006). Slide preparations were pre-treated with a $1: 100$ dilution of RNAse $\left(10 \mathrm{mg} \mathrm{ml}^{-1}\right)$ in $2 \times \mathrm{SSC}$ for $1 \mathrm{~h}$ at $37{ }^{\circ} \mathrm{C}$ in a humidified chamber and washed three times in $2 \times \mathrm{SSC}$ at room temperature for $5 \mathrm{~min}$. The slides were post-fixed in freshly prepared $4 \%\left(\mathrm{w} \mathrm{v}^{-1}\right)$ paraformaldehyde (SIGMA) aqueous solution for $10 \mathrm{~min}$, washed three times in $2 \times$ SSC for $5 \mathrm{~min}$, dehydrated in a graded ethanol series (70, 90 and $100 \%$ ) for $3 \mathrm{~min}$ in each solution, and air dried. Hybridization mixture consisted of $50 \%\left(\mathrm{v} \mathrm{v}^{-1}\right)$ formamide, $10 \%\left(\mathrm{w} \mathrm{v}^{-1}\right)$ dextran sulphate, $0.1 \%\left(\mathrm{w} \mathrm{v}^{-1}\right)$ sodium dodecyl sulphate (SDS), $0.3 \mathrm{mg} \mathrm{ml}^{-1}$ of salmon sperm DNA in $2 \times$ SSC and 100-200 ng of the labeled probes. The hybridization mixture was denatured for $15 \mathrm{~min}$ at $75^{\circ} \mathrm{C}$, and $30 \mu 1$ were loaded onto the slide preparation and covered with a plastic coverslip. The slides were placed on a thermocycler plate at $75^{\circ} \mathrm{C}$ for $7 \mathrm{~min}, 30 \mathrm{~s}$ at $55{ }^{\circ} \mathrm{C}, 1 \mathrm{~min}$ at $45{ }^{\circ} \mathrm{C}, 2 \mathrm{~min}$ at $42{ }^{\circ} \mathrm{C}, 5 \mathrm{~min}$ at $40{ }^{\circ} \mathrm{C}$ and $5 \mathrm{~min}$ at $38{ }^{\circ} \mathrm{C}$. Afterwards, the slides were incubated overnight at $37{ }^{\circ} \mathrm{C}$. The coverslips were carefully floated off by placing the slides in $2 \times \mathrm{SSC}$ at $42{ }^{\circ} \mathrm{C}$ for $5 \mathrm{~min}$, and then washing them for $10 \mathrm{~min}$ with $20 \%$ (v $\mathrm{v}^{-1}$ ) deionized formamide in $0.1 \times \mathrm{SSC}$ at $42{ }^{\circ} \mathrm{C}$ (stringent conditions). Four consecutive rinses were performed at $42{ }^{\circ} \mathrm{C}$ with $0.1 \times \mathrm{SSC}$ for $5 \mathrm{~min} ; 2 \times \mathrm{SSC}$ for $5 \mathrm{~min}$ and twice in $4 \times \mathrm{SSC} /$ Tween $\left(0.2 \% \mathrm{v} \mathrm{v}^{-1}\right)$ for $5 \mathrm{~min}\left(\right.$ at $42{ }^{\circ} \mathrm{C}$ and room temperature). On each slide $100 \mu \mathrm{l}$ of $5 \%$ (w $\mathrm{v}^{-1}$ ) Bovine Serum Albumin (BSA), prepared in $4 \times \mathrm{SSC} /$ Tween $\left(0.2 \% \mathrm{v} \mathrm{v}^{-1}\right)$ at $25{ }^{\circ} \mathrm{C}$ for 5 min, were applied. To detect digoxigenin-labeled probes, one unit of sheep antidigoxigenin FITC (fluorescein isothyocyanate) antibody $\left(\right.$ Roche $\left.^{\circledR}\right)$ was applied per slide, whereas biotin-labeled probes were detected with 0.5 units of streptavidine-Cy3 conjugate antibody $\left(\right.$ SIGMA $\left.^{\circledR}\right)$ per slide. After this, slides were blocked with $5 \%\left(\mathrm{w} \mathrm{v}^{-1}\right)$ BSA and incubated in a 1:40 solution of the corresponding antibody, for $1 \mathrm{~h}$ at $37{ }^{\circ} \mathrm{C}$ in darkness. Then, the slides were washed three times in $4 \times \mathrm{SSC} /$ Tween for $10 \mathrm{~min}$ at room temperature, and afterwards they were counterstained with $100 \mu \mathrm{l}$ of DAPI solution $\left(1 \mu \mathrm{g} \mathrm{ml}^{-1}\right)$ during $30 \mathrm{~min}$ at room temperature and darkness. Finally, they were gently washed in $4 \times \mathrm{SSC}$ and mounted in a drop of anti-fade Vectashield. Chromosome slides were examined in a Leica DMLB microscope equipped with a DFC350 FX CCD camera and IM50 software version 4.0 (Leica Microsystems Imaging solutions). Black and white images were recorded separately for each fluorescent dye, and then colored and processed with Adobe Photoshop CS3 v 10.0 (Adobe Systems Incorporated ${ }^{\circledR}$, USA).

\section{Cytological parameters}

\section{DNA content}

Nuclear suspensions for flow cytometry were prepared by simultaneously chopping $1 \mathrm{~cm}^{2}$ of leaves of a maize individual and of an internal standard (i.e., Pisum sativum cv. Citrad, 2C $=9.09$ pg; Doležel et al. 1998) using a razor blade and immersed in $0.5 \mathrm{ml}$ of Otto I buffer $(100 \mathrm{mM}$ citric acid, $0.5 \%\left(\mathrm{v} \mathrm{v}^{-1}\right)$ Tween $\left.20, \mathrm{pH} \mathrm{2-3}\right)$. The mixture was then filtered through a nylon mesh $(50 \mathrm{~mm})$ and the suspension was treated with $100 \mu \mathrm{l}$ of RNase $\left(10 \mu \mathrm{g} \mathrm{ml}^{-1}\right)$, $2 \mathrm{ml}$ of Otto II buffer $\left(400 \mathrm{mM} \mathrm{Na} 2 \mathrm{PO}_{4} 12 \mathrm{H}_{2} \mathrm{O}\right.$, pH 8-9) and $2 \mathrm{ml}$ of propidium iodide $\left(50 \mu \mathrm{g} \mathrm{ml}^{-1}\right)$. Samples were incubated for approximately $20 \mathrm{~min}$ at room temperature in darkness. The measurements were made on a CyFlow Ploidy Analyser (Partec GmbH, Münster, Germany) at the facility of the 'Instituto de Floricultura-INTA' (Castelar, Buenos Aires, Argentina). Histograms were assessed using the Flowing software 2.5.0 (P. Terho, Turku Centre for Biotechnology, University of Turku, Finland). The total DNA content per diploid genome ( $2 \mathrm{C}$ value) was measured using at least 15 individuals per accession, when possible, with different doses of Bs. For each individual, at least 5,000 nuclei were analyzed. Only nuclear DNA content estimates with a coefficient of variation $<5 \%$ were considered. The DNA content was calculated by multiplying the DNA content of the internal standard (in pg) by the ratio of the mean fluorescent intensity of each sample to that of the standard. The estimation of DNA content from individuals without Bs was referred to as A-DNA content, and estimations from individuals with variable number of Bs were referred to as AB-DNA content. The variation of the ranges between the highest and lowest median A-DNA content values, among accessions, was estimated as: $\left[\left(2 C_{\max }-2 C_{\min }\right) \times 100 / 2 C_{\min }\right]$.

\section{Mean number of knobs}

This parameter was calculated by counting knobs showing DAPI + and FISH positive signals, in at least 10 mitotic metaphases per individual. For each accession, the mean number of knobs was calculated by averaging the counts by the number of analyzed individuals (a minimum of five).

\section{Heterochromatin content}

The percentage of heterochromatin of the A complement (hereafter, A-HC) was estimated from DAPI and/or FISH assays using images of mitotic metaphases, by calculating the percentage of total chromosome length occupied by knob heterochromatin, using MicroMeasure software version 3.3 
(Reeves and Tear 2000). Measurements were based on, at least, 10 mitotic metaphases from each individual and five individuals per accession.

\section{Knob sequence proportions}

The knobs hybridized with 180-bp and/or TR-1 were individually counted to calculate the proportion of each sequence respect to the other using the images obtained from, at least, 10 mitotic metaphases from each individual and five individuals per accession.

\section{Dose, mean number and frequency of Bs}

The number (or dose) of Bs of each individual was determined from preparations of mitotic cells. For each accession, the mean number of Bs was estimated by averaging the sum of B doses among the individuals over the total number of individuals examined. Likewise, the frequency of Bs was calculated as the number of individuals having Bs over the total number of individuals studied (at least 15).

\section{Statistical analyses}

A completely randomized design (Mason et al. 2003) was used to analyze the parameters described above in relation to the cultivation altitude. In order to test the null hypothesis (no differences in the A-DNA content between accessions), a non-parametric Kruskal-Wallis test (K-W test; Daniel 1990) was performed knowing the data were not normally distributed (Shapiro-Wilks: $P<0.0001$ ), see Table S1 and $\mathrm{S} 2$. The $\mathrm{K}-\mathrm{W}$ test was done considering accessions with $n>5$; thus VAV 6630 and VAV 6661 were excluded from this analysis. Correlation analyses were performed with the Pearson method; data used are presented in Table S3. Statistical analyses were carried out with the software Infostat (Di Rienzo et al. 2012) and the R program (R Development Core Team 2015), considering as significant $P$ values $\leq 0.05$; graphics were made using $\mathrm{R}$ program.

\section{Results}

The A-DNA content showed $40 \%$ of difference between the lowest ( $4.5 \mathrm{pg}$ ) and the highest $(6.3 \mathrm{pg}) 2 \mathrm{C}$ value. Significant differences in the A-DNA content were found among accessions (the $\mathrm{K}-\mathrm{W}$ test statistic, $H=69.96$; sample size, $n=98$; $\mathrm{df}=5 ; P<0.0001)$. The landraces Amarillo Grande (VAV 6636) and Orgullo Cuarentón (VAV 6482) exhibited the lowest and the highest $2 \mathrm{C}$ values, respectively. The accessions surveyed were clustered in groups, each composed by accessions of the same landrace (Table 2).
DAPI staining detected that the number of DAPI + knobs was variable among the accessions, ranging from 5 to 19 (Fig. 2; Table 2), although no significant differences were detected $(H=12.89 ; n=58 ; \mathrm{df}=9 ; P=0.163)$. FISH experiments simultaneously using 180-bp and TR-1 sequences as the probes showed that hybridization signals co-localized with the DAPI + bands (Fig. 2a, b). Considering all of the accessions, the knobs with dual hybridization signals were the most frequent $(66.6 \%)$, whereas the knobs hybridized only with the 180-bp or the TR-1 sequences were less abundant (26.3 and $7.06 \%$, respectively).

The A-HC varied from 2.7 to $19.4 \%$ among the accessions. Orgullo Cuarentón (VAV 6482) exhibited the highest A-HC, and its DAPI + bands were notably large (Fig. 2a; Table 2).

The Bs showed DAPI + bands in the distal region of the long arm and these co-localized with hybridization signals of knobs sequences (Fig. 2d-f). The Bs shown by the individuals from landrace Pisingallo exhibited hybridization signals solely with the 180-bp probes (Fig. 2d), whereas individuals from landraces Amarillo Grande and Garrapata had Bs whose knobs hybridized with both 180-pb and TR-1 probes (Fig. 2e, f).

A numerical polymorphism for Bs was found in most of the accessions studied (range, 0-7), and the mean number of Bs varied among the accessions (Table 2). Bs were never detected in those accessions grown below 2020 m.a.s.l., such as VAV 6644 (Amarillo Grande) and VAV 6482 (Orgullo Cuarentón) (Fig. 2a, b). The landrace Garrapata exhibited the highest Bs frequency, all the individuals analyzed from VAV 6662 showed Bs (Fig. 2e, f; Table 2). Individuals having different doses of Bs showed differences in their ABDNA contents (Table 3 ).

Correlation analyses were performed between A-HC, the number and sequence composition of knobs and the cultivation altitudes. The A-HC and the number of knobs exhibited significant negative correlations with the altitude of cultivation (Fig. 3a, b; Table 4). On the other hand, the number of knobs composed of TR-1, 180-bp and 180-bp plus TR-1 sequences showed no significant correlations with the cultivation altitude $[r=-0.07(P=0.671), r=0.17(P=0.273)$ and $r=-0.23(P=0.134)$, respectively] (Fig. 3c). The cultivation altitude correlated positively with the proportion of knobs that hybridized with the 180-bp probe (composed of 180-bp and 180-bp plus TR-1), but correlated negatively with the proportion of knobs that hybridized with the TR-1 probe (composed of TR-1 and 180-bp plus TR-1) (Fig. 3d). The A-DNA content tended to correlate negatively with the altitude of cultivation $(\mathrm{r}=-0.60 ; P=0.1121$; Table 4$)$. The A-DNA content correlated positively with the A-HC $(r=0.71 ; P=0.048$; Fig. 3 e).

The average number and frequency of Bs correlated positively with the cultivation altitude (Fig. 3f; Table 4). A 


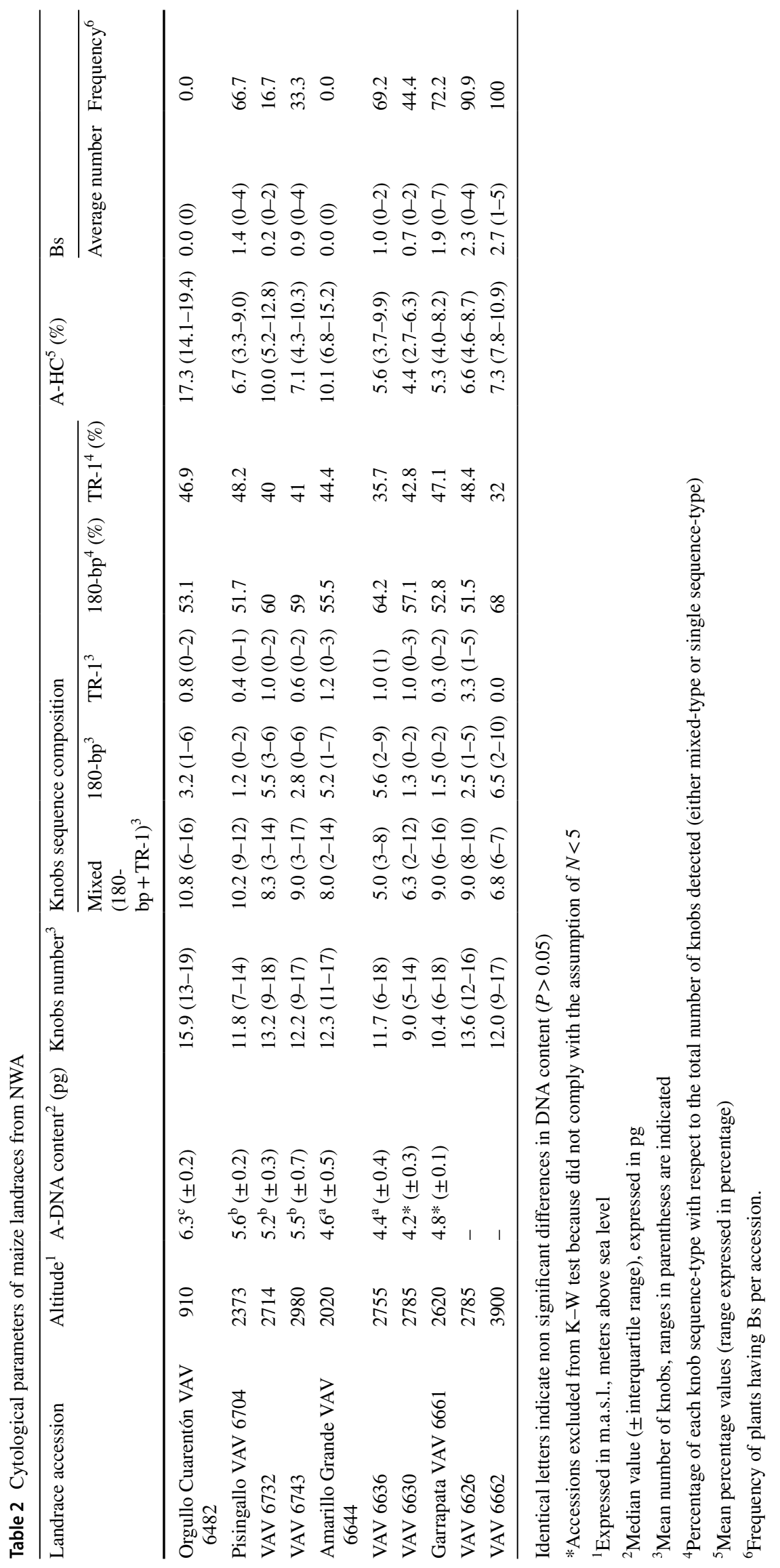



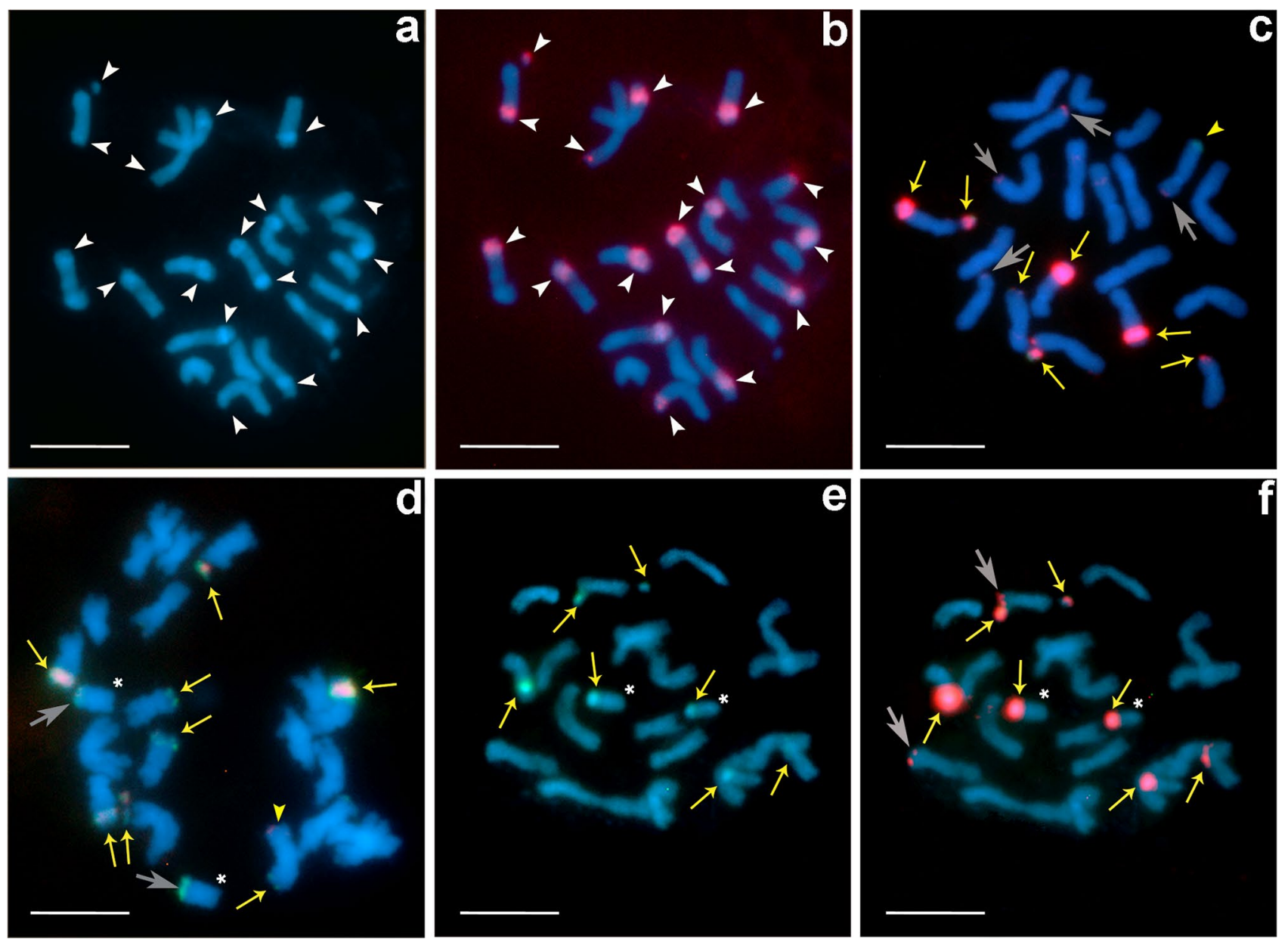

Fig. 2 Mitotic metaphase chromosomes of Argentine maize landraces. a, b Orgullo Cuarentón VAV 6482, a DAPI staining (blue); b FISH using 180-bp sequence as the probe (red). White arrowheads in $\mathbf{a}$ and $\mathbf{b}$ show co-localization of DAPI + and positive hybridization signals. c Amarillo Grande VAV 6636: FISH probed with TR-1 sequence (green) and 180-bp sequence (red). d Pisingallo VAV 6704 with two B chromosomes: FISH probed with TR-1 (red) and 180-bp (green). e, f FISH on Garrapata VAV 6662 with two B chromosomes: e FISH probed with TR-1 (green); f FISH probing 180-bp (red). In c-e, yellow arrows point knobs hybridized with the both sequences of 180-pb and TR-1, grey arrows indicate knobs hybridized exclusively with TR-1 sequence, and yellow arrowheads in (c) and (d) indicate knobs hybridized only with 180 -bp sequence. Asterisks in d-f indicate B chromosomes. Scale bar: $10 \mu \mathrm{m}$ for $(\mathbf{a}, \mathbf{b})$ and $7 \mu \mathrm{m}$ for $\mathbf{c}-\mathbf{f}$. (Color figure online)
Table 3 Median DNA contents of the maize accessions with different doses of B chromosomes (ranges in parentheses)

\begin{tabular}{llllll}
\hline Landrace accession & \multicolumn{4}{l}{ AB-DNA content $(\mathrm{pg})$} \\
\cline { 2 - 6 } & 1 B & 2 Bs & 3 Bs & 4 Bs & 6 Bs \\
\hline OrgulloCuarentón VAV 6482 & - & - & - & - & - \\
Pisingallo VAV 6704 & $5.3( \pm 1.0)$ & $6.3( \pm 0.2)$ & $5.7( \pm 0.3)$ & - & - \\
Pisingallo VAV 6732 & $6.0( \pm 0.2)$ & - & - & - & - \\
Pisingallo VAV 6743 & - & $6.7( \pm 0.2)$ & $5.3( \pm 0.2)$ & - & - \\
Amarillo Grande VAV 6644 & - & - & - & - & - \\
Amarillo Grande VAV 6636 & $5.6( \pm 0.8)$ & - & - & - & - \\
Amarillo Grande VAV 6630 & $4.7( \pm 0.1)$ & $4.7( \pm 0.1)$ & - & - & - \\
Garrapata VAV 6661 & $5.6( \pm 1.1)$ & - & $5.6( \pm 0.2)$ & - & - \\
Garrapata VAV 6626 & $5.9( \pm 0.3)$ & - & $6.2( \pm 1.0)$ & $6.5( \pm 0.1)$ & - \\
Garrapata VAV 6662 & - & $5.5( \pm 0.5)$ & - & - & $6.6( \pm 0.2)$
\end{tabular}


a

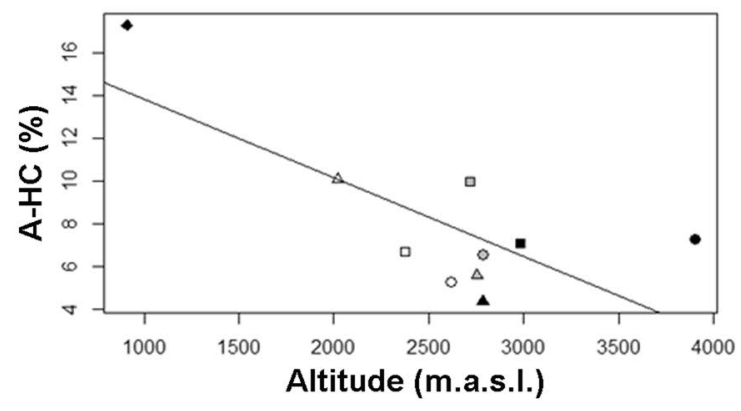

c
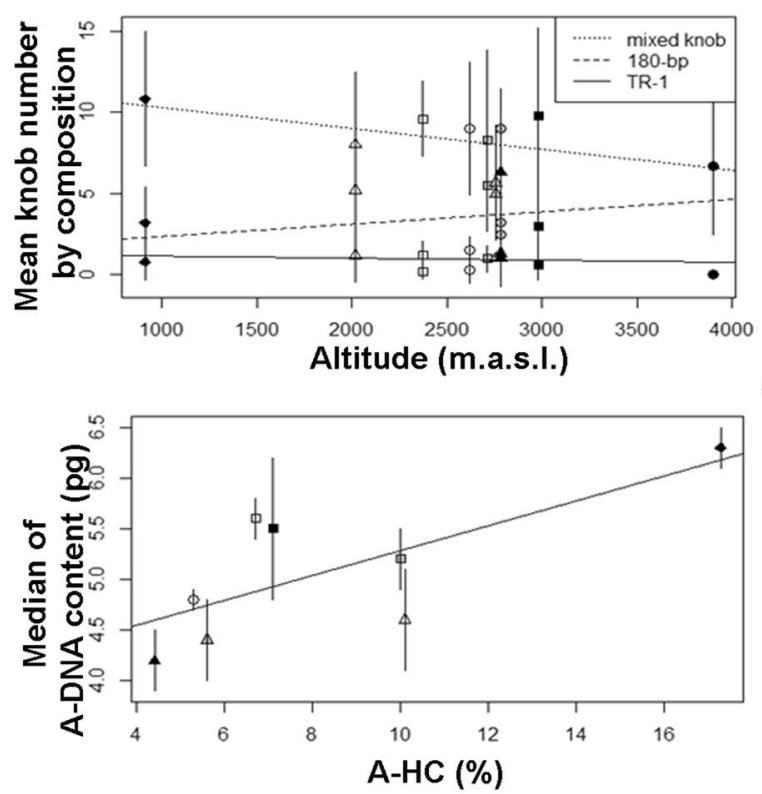

g

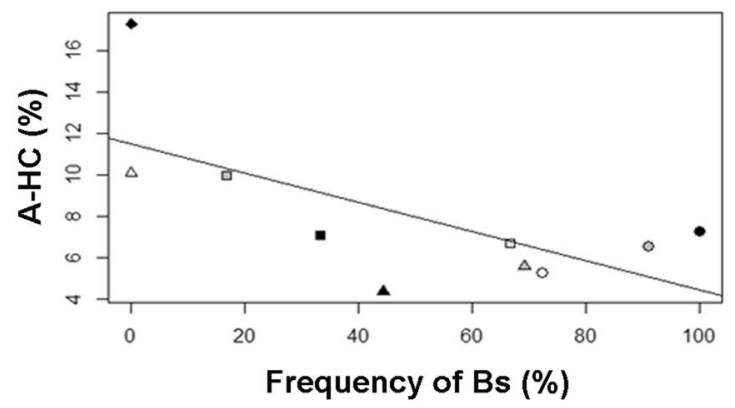

Fig. 3 Scatter plot of correlations among cytological and environmental parameters. a Heterochromatin amount vs. altitude of cultivation. b Mean number of knobs vs. altitude of cultivation. $\mathbf{c}$ Knob number according its sequence composition vs. altitude of cultivation. d Amount of knob sequences vs. altitude of cultivation. e A-DNA content vs. heterochromatin amount, the Garrapata (VAV 6626) and Garrapata (VAV 6662) A-DNA content was not determined due to their very low frequency of $0 \mathrm{~B}$ individuals. $\mathbf{f}$ Frequency of Bs vs. altitude of cultivation. $\mathrm{g}$ Heterochromatin percentage vs. frequency of Bs. $\mathbf{h}$ Total DNA content vs. dose of Bs, asterisks mean of AB-

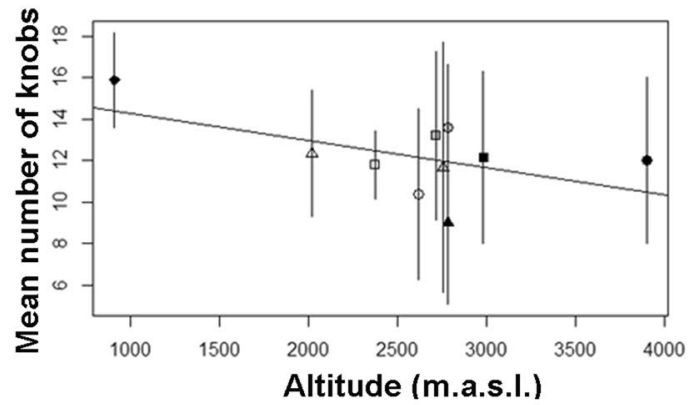

d

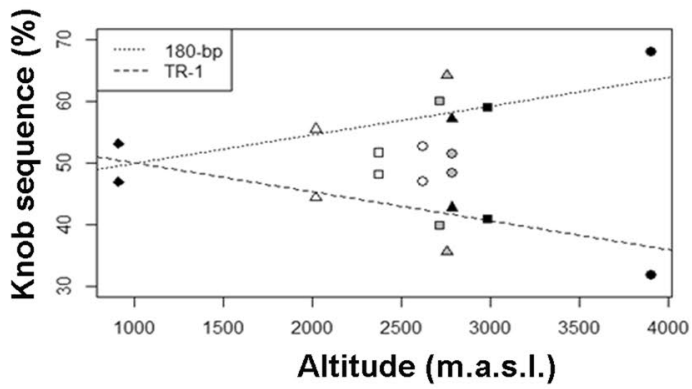

e

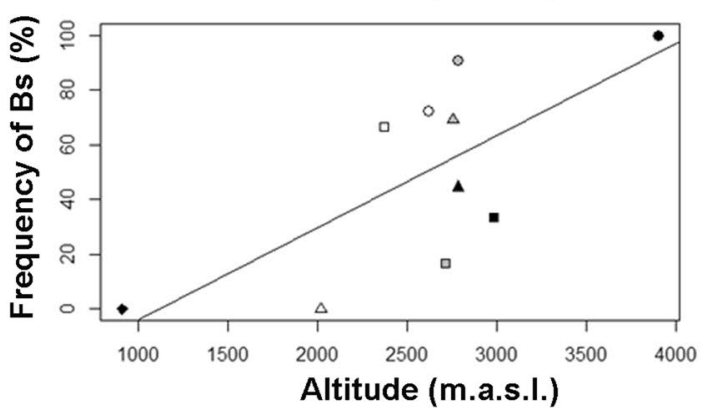

h

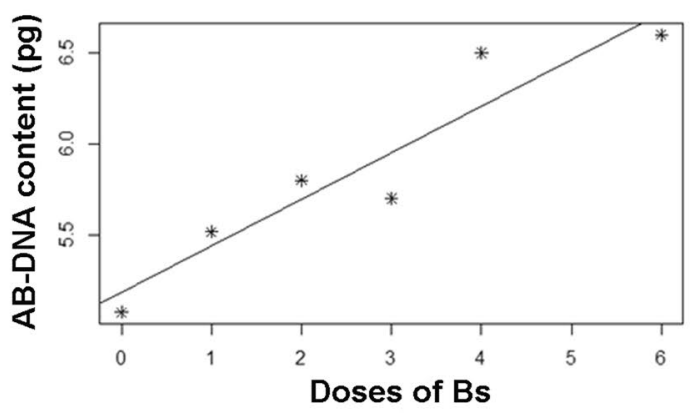

DNA content of individuals with different dose of Bs, independently of their landrace. Ref.: m.a.s.l.: meters above sea level; black filled diamond, Orgullo Cuarentón (VAV 6482); open square, Pisingallo (VAV 6704); grey filled square, Pisingallo (VAV 6732); black filled square, Pisingallo (VAV 6743); open triangle, Amarillo Grande (VAV 6644); grey filled triangle, Amarillo Grande (VAV 6636); black filled triangle, Amarillo Grande (VAV 6630); open circle, Garrapata (VAV 6661); black filled circle, Garrapata (VAV 6626); grey filled circle, Garrapata (VAV 6662) 
Table 4 Pearson's correlations between cytological parameters and the altitude of cultivation

\begin{tabular}{lcc}
\hline Cytological parameters & \multicolumn{2}{c}{ Altitude of cultivation } \\
\cline { 2 - 3 } & $\mathrm{r}$ & $\mathrm{P}$ \\
\hline A-DNA content & -0.60 & 0.1121 \\
Mean number of knobs & -0.31 & 0.0198 \\
A-HC & -0.74 & 0.0135 \\
180-bp (\%) & 0.64 & 0.0482 \\
TR-1 (\%) & -0.64 & 0.0473 \\
Mean number of Bs & 0.68 & 0.0287 \\
Frequency of Bs & 0.71 & 0.0221 \\
\hline
\end{tabular}

Significant values are considered with $P \leq 0.05$

negative correlation was found between A-HC and the frequency of Bs ( $r=-0.68 ; P=0.0310$; Fig. $3 g$ ). The AB-DNA content showed a positive correlation with the doses of Bs ( $r=0.55 ; P=0.0049$; Fig. 3h).

\section{Discussion}

We studied the genome sizes (2C values) of 10 accessions of four maize landraces grown along a broad altitudinal cline, ranging from 910 to 3900 m.a.s.l., in Northwestern Argentina. The $2 \mathrm{C}$ value determinations were performed in plants without Bs to assess variation in DNA content of the A chromosomes (A-DNA), regardless of the variation caused by Bs. The difference between the lowest ( $4.5 \mathrm{pg}$ ) and the highest (6.3 pg) A-DNA content (2C value) was $40 \%$ of the lowest content. Previous studies performed in the same geographical area, reported a $36 \%$ difference between the lowest and the highest $2 \mathrm{C}$ values of maize landraces growing from 80 to 3620 m.a.s.l. (Rosato et al. 1998). The genome size variation detected in the landraces analyzed herein is the largest among those recorded to date in populations from the American continent (Díez et al. 2013; Ho and Rayburn 1991; McMurphy and Rayburn 1991; Rayburn 1990; Rayburn and Auger 1990; Rayburn et al. 1985, 1994; Tito et al. 1991). This variation could be attributed to the effect of selection acting, directly or indirectly, on nuclear and chromosomal characteristics in different environmental conditions along the altitudinal cline. Díez et al. (2013) suggested that the A-DNA content of inbred lines and landraces from Mexico may be affected by selection acting on 'multiple phenotypes' (such as the growth rate, the flowering time, the seed mass, the leaf size or photosynthetic rate) adapted to different environments. Several studies reported positive relationships of the DNA content with phenotypic and cytological characteristics suggesting a biological role to genome size (reviewed in Greilhuber and Leitch 2013). This is in agreement with the significant differences in the A-DNA content detected in the present study among the Orgullo Cuarentón, Amarillo Grande and Pisingallo landraces.

Several authors have documented either positive or negative correlations of the latitude or the altitude of cultivation with genome size, number of knobs and number of Bs, at different maize cultivation sites around the world, suggesting the existence of 'adaptive clines' (Díez et al. 2013; Poggio et al. 1998). The data gathered here for A-DNA content showed a clear downward trend in relation to the cultivation altitude. Likewise, Rosato et al. (1998) found a significant negative correlation between A-DNA content and altitude, studying a similar altitudinal cline in NWA. These concordant results suggest that the genome size could be related to a rapid vegetative growth and early flowering in the shortened growing seasons, being typical of cool highland regions (Bennett and Leitch 2005; Laurie and Bennett 1985; Poggio et al. 1998; Rayburn 1990; Rayburn and Auger 1990; Rayburn et al. 1994; Rosato et al. 1998). Recent data suggest that selection on genome size may be operating at the level of cell production rate (Bilinski et al. 2017).

Rosato et al. (1998) detected a highly variable number of knobs using only DAPI banding in maize populations from NWA. Herein, the number of knobs was estimated both through DAPI banding and fluorescent in situ hybridization. The sensitivity of FISH allowed detecting knobs more accurately than the $\mathrm{C}$ or DAPI banding methods, even in the cases where the knob sequences were in low copy numbers. This higher sensitivity resulted in the detection of higher number of knobs in the present work $(\leq 19)$, compared to those reported by McClintock et al. (1981) and Rosato et al. (1998).

The average number of knobs did not differ significantly among the accessions studied. However, accessions from the same landrace, not differing in their A-DNA content, varied greatly in their number of knobs. No significant correlation was ever observed between the mean number of knobs and the A-DNA content. Nevertheless, the A-HC showed a positive correlation with the A-DNA content. These results indicate that the A-DNA content variation could be mainly due to differences in the sizes of the knobs, and not in their numbers.

We observed that A-HC was negatively correlated with the cultivation altitude, agreeing with previous reports (Poggio et al. 1998; Price 1988; Tito et al. 1991). Several authors found a positive correlation between the A-HC and the vegetative period, and suggested that the reduction of A-HC along an altitudinal cline reflected an adaptation to a shorter growing season at high altitude (Price 1988; Rayburn et al. 1985; Tito et al. 1991). Realini et al. (2016) found a positive correlation between the length of the vegetative cycle and the A-HC in maize landraces from the Northeastern Argentina, and hypothesized that the length of the vegetative cycle would be optimized via selection for an 
appropriate percentage of heterochromatin. This reinforces the idea that the A-HC has adaptive significance along the altitudinal cline.

FISH experiments allowed detecting the component sequences of knobs heterochromatin in $\mathrm{A}$ and $\mathrm{B}$ chromosomes, where 180-bp and TR-1 repeats were found as combined or isolated. Even though significant correlations had been found between knob sequence composition and cultivation altitude, the proportion of knobs with the 180$\mathrm{pb}$ sequence was consistently higher than those with TR-1 sequence along the altitudinal gradient. Kanizay et al. (2013) found similar relative abundances of both 180-pb and TR-1 sequences, and suggested that the two repeats can operate in competition with each other. It must be noted that their studies involved maize plants with a chromosome 10 variant, known as abnormal 10 (Ab-10), carrying genes involved in meiotic drive. However, this Ab-10 has not been recognized so far in NWA maize landraces. The differences in the relative proportion of 180-bp and TR-1 repeats could probably be due to selective forces.

In maize, the Bs have been widely studied and are sources of genome size variation (Cheng and Lin 2003; Jin et al. 2005; Lamb et al. 2007; Lia et al. 2007; McClintock et al. 1981; Poggio et al. 1998; Rosado et al. 2009). Our results show that the mean number of Bs differ significantly among the accessions, and that a positive correlation can be established between the cultivation altitude and the number of Bs. Ayonoadu and Rees (1971) found that each Bs increased 5\% of the total DNA content. In contrast, our study showed variable increments of DNA contents along with the doses of Bs. This variation could be accounted for to the polymorphism/ polytypism for the number and size of knobs that also cause variations in the total nuclear DNA content, including genic and non-genic DNAs (nucleotype; sensu Bennett 1972). The term nucleotype define conditions of the nuclei that affect cellular and developmental parameters such as chromosome size, nuclear volume, cellular volume, mitotic cycle time, duration of meiosis and minimum generation time (Bennett 1972, 1987; Poggio et al. 1998). The negative association observed between the frequency of Bs and the A-HC suggests that there is a maximum limit to the mass of nuclear DNA to maintain the optimum nucleotype.

Bs were found in all the accessions cultivated above 2020 m.a.s.l., with the highest frequency of Bs (100\%) in the Garrapata landrace (VAV 6662) at 3900 m.a.s.l. However, Rosato et al. (1998) did not detect Bs in populations cultivated above 3200 m.a.s.l. These results suggest that the frequency of Bs depends not only on the cultivation altitude, but also on the genotypical and nucleotypical backgrounds of the landraces. Molecular marker studies in maize landraces from NWA showed that the maintenance of the altitudinal cline of Bs might be a product of selective forces (Lia et al. 2007). These authors proposed that clinal variation may arise either as a consequence of a beneficial effect of $\mathrm{Bs}$ at higher elevations or as a result of Bs being negatively selected at lower elevations. Altitudinal and longitudinal clines for phenotypic and genetic traits have been interpreted as the evidence of selection, for instance a significant negative correlation was found between A-DNA content and altitude of cultivation and between A-DNA content and mean number of Bs (Rosato et al. 1998). Díez et al. (2013) argued about the indirect action of selection on DNA content, through a multiplicity of phenotypes and life-history traits. Therefore, the positive correlation of mean number and frequencies of Bs with the cultivation altitude that we found would further support to this selective hypothesis.

In conclusion, we confirm that $\mathrm{A}-\mathrm{HC}$ and $\mathrm{Bs}$ are the main sources for the variation of the A-DNA content detected among the maize landraces studied herein. Moreover, present results suggest that the frequencies and doses of Bs are influenced by the landrace genotypical make-up. As suggested by the significant correlations found herein among the cytological parameters studied (i.e., A-DNA content, A-HC, number of knobs and presence of $\mathrm{Bs}$ ) and the cultivation altitude, selective forces acting along the altitudinal gradient might be modulating the nucleotype of the northwestern Argentinian landraces.

Acknowledgements The authors wish to thank to the loving memory Ing. Agr. Julián Cámara-Hernández (Laboratorio Vavilov, Facultad de Agronomía, Universidad de Buenos Aires) for his dedication, invaluable assistance, and taxonomic determination of all the materials used; to Dr. Verónica Lia (Laboratorio de Biotecnología, Instituto Nacional de Tecnología Agropecuaria, Argentina) for sharing seeds from VAV 6482 of Orgullo Cuarentón landrace; to Dr. Jaroslav Doležel (Laboratory of Molecular Cytogenetics and Cytometry, Institute of Experimental Botany, Czech Republic) for sharing Pisum sativum cv. Citrad seeds; to Dr. Gerardo Cueto (Facultad de Ciencias Exactas y Naturales, Universidad de Buenos Aires) for his helpful advice with the statistical analyses; to Lic. Lucía Babino (IEGEBA, UBA-CONICET) for her support with the graphics, and to Mr. Diego Fink for his technical assistance improving the cytological figures. This research was funded by grants from the University of Buenos Aires (UBACYT 20020130100694BA), and the National Council of Scientific Research (CONICET-PIP 11220120100107CO). The authors are fellows of CONICET.

\section{References}

Ananiev EV, Phillips RL, Rines HW (1998) A knob associated tandem repeat in maize capable of forming fold-back DNA segments: are chromosome knobs megatransposons? Proc Natl Acad Sci USA 95:10785-10790

Ayonoadu UW, Rees H (1971) The effects of B-chromosomes on the nuclear phenotype in root meristems of maize. Heredity 27:365-383

Bennett MD (1972) Nuclear DNA content and minimum generation time. Proc R Soc Lond B 181:109-135

Bennett MD (1987) Variation in genomic form in plants and its ecological implications. New Phytol 106:177-200 
Bennett MD, Leitch IJ (2005) Nuclear DNA amounts in angiosperms: progress, problems and prospects. Ann Bot 95:45-90

Bilinski P, Albert PS, Berg JJ, Birchler JA, Grote M, Lorant A, Quezada J, Swarts K, Yang J, Ross-Ibarra J (2017) Parallel altitudinal clines reveal adaptive evolution of genome size in Zea mays. BiorXiv. https://doi.org/10.1101/134528

Bracco M, Lia VV, Gottlieb AM, Cámara Hernández J, Poggio L (2009) Genetic diversity in maize landraces from indigenous settlements of Northeastern Argentina. Genetica 135:39-49

Bretting PK, Goodman MM (1989) Karyological variation in Mesoamerican races of maize and its systematic significance. Econ Bot 43:107-124

Bullock D, Rayburn AL (1991) Genome size variation in Southwestern US Indian maize populations may be a function of effective growing season. Maydica 36:247-250

Cámara Hernández J, Miante Alzogaray AM, Bellon R, Galmarini AJ (2012) Razas del noroeste argentino. In: Facultad de Agronomía, Universidad de Buenos Aires (ed) Razas de maíz nativas de la Argentina, vol 1. Buenos Aires, p 192

Cheng YM, Lin BY (2003) Cloning and characterization maize B chromosome sequences derived from microdissection. Genetics 164:299-310

Chiavarino AM, Rosato M, Naranjo CA, Camara Hernandez J, Poggio L (1995) B chromosome polymorphism in N.W. Argentine populations of maize. Maize Genetics Cooperation Newsletters. http:// www.agron.missouri.edu/mnl/69/108chiavarino.html

Daniel WW (1990) Applied nonparametric statistic. PWS-Kent Publ, Devon

Di Rienzo JA, Casanoves F, Balzarini MG, Gonzalez L, Tablada M, Robledo CW (2012) Grupo Infostat, FCA, Universidad Nacional de Córdoba, Argentina. http://www.infostat.com.ar

Díez CM, Gaut BS, Meca E, Scheinvar E, Montes-Hernandez S, Eguiarte LE, Tenallion MI (2013) Genome size variation in wild and cultivated maize along altitudinal gradients. New Phytol 199:264-276

Doležel J, Greilhuber J, Lucretti S, Meister A, Lysák MA, Nardi L, Obermayer R (1998) Plant genome size estimation by flow cytometry: inter-laboratory comparison. Ann Bot 82:17-26

Fourastié MF (2015) Estudios citogenéticos en razas de maíz del NOA: Caracterización cariotípica, evaluación del tamaño del genoma y frecuencia de cromosomas B. Dissertation. Universidad de Buenos Aires

González GE, Comas C, Confalonieri VV, Naranjo C, Poggio L (2006) Genomic affinities between maize and Zea perennis using classical and molecular cytogenetic methods (GISH-FISH). Chrom Res 14:629-635

González GE, Fourastié MF, Poggio L (2013) Relevancia del número y composición de secuencias de los nudos cromosómicos en la caracterización de maíz y teocintle. Rev Fitotec Mex 36:127-135

Greilhuber J, Leitch IJ (2013) Genome size and the phenotype. In: Leitch IJ, Greilhuber J, Dolezel J, Wendel JF (eds) Plant genome diversity, vol 2. Springer, Vienna, pp 323-340

Ho I, Rayburn AL (1991) The relationship between chloroplast number and genome size in Zea mays ssp. mays. Plant Sci 74:255260

Jin W, Lamb JC, Vega JM, Dawe RK, Birchler JA, Jiang J (2005) Molecular and functional dissection of maize B chromosome centromere. Plant Cell 17:1412-1423

Kanizay LB, Albert PS, Birchler JA, Dawe K (2013) Intragenomic conflict between the two major knob repeats of maize. Genetics 194:81-89. https://doi.org/10.1534/genetics.112.148882

Kato TA (1976) Cytological studies of maize (Zea mays L.) and teosinte (Zea mexicana Schrader Kuntze) in relation to their origin and evolution. Bull Mass Agric Exp Stn 635:1-185

Kato TA, Mapes C, Mera IM, Serratos JA, Bye RA (2009) Origen y diversificación del maíz: una revisión analítica. In: Galindo Leal C (ed) Universidad Nacional Autónoma de México, Comisión
Nacional para el conocimiento y uso de la biodiversidad, vol 1. México DF, p 116

Lamb JC, Meyer JM, Corcoran B, Kato A, Han F, Birchler JA (2007) Distinct chromosomal distributions of highly repetitive sequences in maize. Chrom Res 15:33-49

Laurie DA, Bennett MD (1985) Nuclear DNA content in the genera Zea and Sorghum. Intergeneric, interespecific and intraspecific variation. Heredity 55:307-313

Lia VV, Confalonieri VA, Poggio L (2007) B chromosome polymorphism in maize landraces: adaptive vs demographic hypothesis of clinal variation. Genetics 107:896-904

Lia VV, Poggio L, Confalonieri VA (2009) Microsatellite variation in maize landraces from Northwestern Argentina: genetic diversity, population structure and racial affiliations. Theor Appl Genet 119:1053-1067

Mason RL, Gunst RF, Hess JL (2003) Statistical design and analysis of experiments: with applications to engineering and science, 2nd edn. Wiley, New Jersey

McClintock B, Kato TA, Blumenschein A (1981) Constitución cromosómica de las razas de maíz. Su significado en la interpretación de relaciones entre las razas y variedades en las Américas. Colegio de Postgraduados. Chapingo, México

McMurphy LM, Rayburn AL (1991) Genome size variation in maize populations selected for cold tolerance. Plant Breed 106:190-195

McMurphy LM, Rayburn AL (1992) Chromosomal and cell size analysis of cold tolerant maize. Theor Appl Genet 84:798-802

Mondin M, Santos-Serejo JA, Bertão MR, Laborda P, Pizzaia D, Aguiar-Perecin MLR (2014) Karyotype variability in tropical maize sister inbred lines and hybrids compared with KYS standard line. Front Plant Sci 5:1-12

Peacock WJ, Dennis ES, Rhoades MM, Pryor AJ (1981) Highly repeated DNA sequences limited to knob heterochromatin in maize. Proc Natl Acad Sci USA 78:4490-4494

Poggio L, Rosato M, Chiavarino AM, Naranjo CA (1998) Genome size and environmental correlations in maize (Zea mays ssp. mays, Poaceae). Ann Bot 82:107-115

Porter HL, Rayburn AL (1990) B-chromosome and C-band heterochromatin variation in Arizona maize populations adapted to different altitudes. Genome 33:659-662

Price HJ (1988) DNA content variation within angiosperm species. Ann Mo Bot Gard 75:1248-1257

Puertas MJ, Jimenez G, Manzanero S, Chiavarino AM, Rosato M, Naranjo CA, Poggio L (2000) Genetic control of B chromosome transmission in maize and rye. In: Olmo E, Redi CA (eds) Chromosomes today, vol 13, Birkhäuser Verlag, Switzerland pp 79-91

R Development Core Team (2015) R: a language and environment for statistical computing. R Foundation for Statistical Computing, Vienna

Rayburn AL (1990) Genome size variation in Southern United States Indian maize adapted to various altitudes. Evol Trend Plant 4:53-57

Rayburn AL, Auger JA (1990) Genome size variation in Zea mays ssp. mays adapted to different altitudes. Theor Appl Genet 79:470-474

Rayburn AL, Price HJ, Smith JD, Gold JR (1985) C-band heterochromatin and DNA content in Zea mays. Am J Bot 72:1610-1617

Rayburn AL, Auger JA, Benzinger EA, Hepburn AG (1989) Detection of intraspecific DNA content variation in Zea mays L. by flow cytometry. J Exp Bot 40:1179-1183

Rayburn AL, Biradar DP, Bullock DG, McMurphy LM (1993)) Nuclear DNA content in F1, hybrids of maize. Heredity 70:294-300

Rayburn AL, Dudley JW, Biradar DP (1994) Selection for early flowering results in simultaneous selection for reduced nuclear DNA content in maize. Plant Breed 112:318-322

Realini MF, Poggio L, Cámara-Hernández J, González GE (2016) Intra-specific variation in genome size in maize: cytological and phenotypic correlates. AoB Plants 8:plv138 
Reeves A, Tear J (2000) MicroMeasure for Windows, version 3.3. http://rydberg.biology.colostate.edu/MicroMeasure/

Rosado TB, Clarindo WR, Carvalho CR (2009) An integrated cytogenetic, flow and image procedure used to measure the DNA content of Zea mays and B chromosomes. Plant Sci 176:154-158. https:// doi.org/10.1016/j.plantsci.2008.10.007

Rosato M, Chiavarino A, Naranjo CA, Cámara Hernández J, Poggio L (1998) Genome size and numerical polymorphism for
B-chromosome races of maize (Zea mays ssp. mays, Poaceae). Am J Bot 85:168-174

Rozen S, Skaletsky H (2000) Primer3 on the www for general users and for biologist programmers. Methods Mol Biol 132:365-386

Tito C, Poggio L, Naranjo CA (1991) Cytogenetics studies in the genus Zea: DNA content and heterochromatin in species and hybrids. Theor Appl Genet 83:58-64 